\title{
MAJOR ARTICLES
}

\section{Infections with Viruses and Mycoplasma pneumoniae during Exacerbations of Chronic Bronchitis}

R. O. Buscho, D. Saxtan, P. S. Shultz,

E. Finch, and M. A. Mufson
From the Veterans Administration West Side Hospital, and the Departments of Medicine and of Preventive Medicine and Community Health, Abraham Lincoln School of Medicine, University of Illinois at the Medical Center, Chicago, Illinois

\begin{abstract}
The association of viral and Mycoplasma pneumoniae infections with acute exacerbations of chronic bronchitis was studied by serologic or isolation techniques in 46 adult men during the five years from 1964 through 1968. Serologic evidence of viral or $M$. pneumoniae infcction was detected in $25 \%$ of 166 episodes of exacerbation and $14 \%$ of 138 remission periods $(P=0.02)$. Influenza $A$ virus, parainfluenza virus type 3, and coronavirus OC43 predominated; infections with other viruses were infrequent. Infection with $M$. pneumoniae was detected serologically in four patients, but this organism was never isolated from sputum specimens. Rhinoviruses were isolated from frozen-stored sputum specimens in $2.7 \%$ of the episodes of exacerbation and from $0.55 \%$ of the remission intervals ( $P$ not significant). These data suggest that although exacerbations of chronic bronchitis may be accompanied by viral and $M$. pneumoniae infections, patients with chronic bronchitis also acquire such infections without a worsening of their respiratory status.
\end{abstract}

Most of the microorganisms that infect the respiratory tract can be recovered from individuals undergoing exacerbations of chronic bronchitis $[1,2]$. However, the role of viral and mycoplas mal infections in exacerbations of chronic bronchitis has not been fully documented. Moreover, the observations regarding infections in chronic bronchitics in a designated patient population during any specified period may not be comparable to those in other populations. Because of the high prevalence and morbidity of chronic bronchitis among patients of Veterans Administration Hospitals, we have conducted surveillance of one of these groups to assess the impact of respiratory tract infections on the natural course of this disease and to investigate further the occurrence and relative importance of viruses and mycoplas. mas in exacerbations [3]. Evidence of viral and Mycoplasma pneumoniae infections (obtained

Received for publication July 19, 1976, and in revised form November 14, 1977.

Please address requests for reprints to Dr. M. A. Mufson at his prescnt addrcss: Department of Medicine, Marshall University School of Medicine, Huntington, West Virginia 25701 . mainly by serologic testing and to a lesser extent by isolation of organisms) was correlated with the pattern of clinical disease in patients with chronic bronchitis.

\section{Materials and Methods}

Design of study. Forty-six male adults with chronic bronchitis, outpatients at the Veterans Administration Hospital, Hines, Ill., constituted the study group. These patients all fulfilled the criteria for the diagnosis of chronic bronchitis, defined as a chronic or recurrent increase in the volume of mucoid or mucopurulent bronchial secretions sufficient to cause expectoration, during at least three months of each of the two years prior to entry into the study group. Their clinical and microbiological status was studied longitudinally during the five years from 1964 through 1968. Monthly or in alternate months and during periods of exacerbation, each patient reported to the outpatient clinic for examination. At each visit a symptom questionnaire was completed by the examiner, a physical examination was performed, pulmonary function tests were 
done, a sputum specimen was collected for isolation of virus and $M y$ coplasma, and a serum specimen was obtained for serologic evaluation. The questionnaires and definitions of remissions and exacerbations were modeled after the guidelines reported by the Medical Research Council [4]. Exacerbations were defined as an increase in cough or sputum production since the patient's previous visit. Symptoms of upper airway infection were not included among these criteria.

An exacerbation was considered satisfactorily tested for viral and $M$. pneumoniae infections when serum pairs were obtained before and after this episode and a sputum specimen was collected'for mycoplasmal and viral isolation. One hundred sixty-six $(62 \%)$ of 270 exacerbations were tested in this manner. For comparison, 138 intervals when patients did not experience an exacerbation or were otherwise in remission were similarly tested.

Population characteristics. All patients were veterans who attended the pulmonary outpatient clinic on a regular basis. They visited the clinic for monthly follow-up an average of 10.3 months per year and made an average of 11.0 total visits per year. Persons who were habitual poor attenders were not included in the study population. The ages of the 46 patients at the beginning of the study period ranged from 31 to 79 years; the distribution of age was as follows: 30-39 years, two patients; $40-49$ years, $13 ; 50$ 59 years, nine; 60-69 years, 13 ; and $70-79$ years, nine. The median age decade was 50-59 years. All patients were or had been cigarette smokers. The range of pack-years (one pack per man per year) was five to 125 (median, 49 years). Pulmonary function tests on entry into the study disclosed a marked degree of obstructive pulmonary disease. The mean values of forced vital capacity (FVC), forced expiratory volume $\left(\mathrm{FEV}_{1}\right)$, and the ratio $\mathrm{FEV}_{1} / \mathrm{FVC}$ were 2.45 liters, 1.31 liters, and $52 \%$. Expressed as a percentage of normal, the $\mathrm{FEV}_{1}$ for study patients ranged from $10 \%$ to $80 \%$, but two-thirds of the group had values of $\leq 40 \%$. Similarly, the $\mathrm{FEV}_{1} / \mathrm{FVC}$ ratio ranged from $30 \%$ to $80 \%$ of normal, and two-thirds of the group had values of $\leq 50 \%$.

Procedures for isolation of virus. Sputum specimens for viral isolation were stored at $-70 \mathrm{C}$ for five to eight years. When ready for use, speci- mens were rapidly thawed, and $0.4 \mathrm{ml}$ was suspended in $2.0 \mathrm{ml}$ of chilled veal infusion broth treated with 500 units of penicillin $/ \mathrm{ml}, 500 \mu \mathrm{g}$ of streptomycin $/ \mathrm{ml}$, and $0.02 \mathrm{mg}$ of amphotericin $\mathrm{B} / \mathrm{ml}$ of broth for $1 \mathrm{hr}$ at $4 \mathrm{C}$. A volume of $0.2 \mathrm{ml}$ of the treated sputum suspension was inoculated into each of two roller-tube cultures of human diploid fibroblasts (WI-38 strain) for recovery of picornaviruses, adenoviruses, herpesviruses, and coronavirus strain 229E. Because of the long period of storage of the sputum specimens, no attempt was made to isolate myxoviruses.

WI-38 roller-tube cultures were obtained from Flow Laboratories, Rockville, Md. Maintenance medium for these cell cultures consisted of Eagle's minimal essential medium supplemented with $2 \%$ inactivated fetal calf serum; the complete medium was adjusted to $\mathrm{pH} 7.0$ with $7.5 \%$ $\mathrm{NaHCO}_{3}[5]$.

Cultures were incubated on a rotating drum at $33 \mathrm{C}$ for at least 21 days and often for as long as 28 days. Subpassages of negative cultures were not made. Cell cultures were examined three times a week for $\mathrm{CPE}$, and the maintenance medium was changed at these times. Viral isolates were identified by procedures previously described [5].

Mycoplasma. A fresh agar medium consisting of pleuropneumonia-like organism agar (Difco, Detroit, Mich.), 20\% horse serum, $10 \%$ yeast extract, penicillin $\mathrm{G}(2,000$ units $/ \mathrm{ml})$, amphotericin B $(5.6 \mu \mathrm{g} / \mathrm{ml})$, and thallium acetate $(0.05 \%)$ was used for the isolation of all mycoplasmas. Duplicate plates were inoculated with sputum. One plate was incubated aerobically and the other anerobically at $37 \mathrm{C}$ for four weeks. Mycoplasma isolates were identified by growth inhibition procedures using specific hyperimmune antiserum [6]. Included in the test were antisera to $M$. pneumoniae, Mycoplasma orale, Mycoplasma hominis, Mycoplasma fermentans, Mycoplasma arthriditis, and Mycoplasma salivarium. Approximately one-half of the cultures were passaged on agar a second time from an area selected adjacent to the zone of inhibition in an attempt to identify mixed cultures of mycoplasmas. None were detected.

Serologic procedures. Serial serum specimens were tested by CF for antibodies to influenza $A$ and $B$ viruses, respiratory syncytial virus (RSV), 
parainfluenza virus types 1,2 , and 3 , adenoviruses, and coronavirus types $229 \mathrm{E}$ and $\mathrm{OC} 43$ and for $M$. pneumoniae. Microtiter CF tests containing 1.71.8 units of complement were cmployed after fixation overnight at $4 \mathrm{C}$. Four units of each viral and mycoplasmal antigen were used. Serologic evidence of infection was defined as a fourfold or greater rise in antibody titer between the acuteand convalescent-phase sera.

\section{Results}

Occurrence of acute respiratory illness in patients with chronic bronchitis. The total number of exacerbations experienced by each patient during their participation in this study ranged from one to 14 (mean, 5.9). The number of ex. acerbations of any one patient usually was directly proportional to the number of years of participation in the surveillance program. The mean number of years of patient participation was 3.7. Only one patient reported no exacerbations during the four-year period of the study. Exacerbations of chronic bronchitis tended to occur more often in the winter months than in the summer months, although they occurred frequently in all months of the year (table 1).

Serologic evidence of viral and $M$. pneumoniae infections. Infections with respiratory virus or $M$. pneumoniae were detected at least once in 40 of the 46 patients studied. The mean num-

Table 1. Occurrence (by month) of total and tested exacerbations among patients with chronic bronchitis from 1964 through 1968.

\begin{tabular}{lcr}
\hline Month & $\begin{array}{c}\text { No. of } \\
\text { exacerbations }\end{array}$ & $\begin{array}{c}\text { No. of } \\
\text { exacerbations } \\
\text { tested (\%) }\end{array}$ \\
\hline January & 27 & $22(81.5)$ \\
February & 20 & $10(50.0)$ \\
March & 26 & $17(65.4)$ \\
April & 18 & $10(55.6)$ \\
May & 23 & $13(56.5)$ \\
June & 18 & $11(61.1)$ \\
July & 18 & $13(72.2)$ \\
August & 22 & $16(72.7)$ \\
September & 23 & $17(73.9)$ \\
October & 21 & $12(57.1)$ \\
November & 27 & $16(59.3)$ \\
December & 27 & $9(33.3)$ \\
Total & 270 & $166(61.5)$ \\
\hline
\end{tabular}

ber of infections was 1.9 (range, 1-6). Although patients included in the study for a longer time experienced somewhat more virus and $M$. pneumoniae infections, the relationship was not linear, a finding suggesting that individual differences in rates of infection could not be attributed exclusively to the duration of participation in the study.

Fourfold or greater rises in titer of antibody to virus or $M$. pneumoniae were detected in 50 (30.1\%) of 166 exacerbations of chronic bronchitis in the 46 adult patients studied (table 2). By comparison, viral and $M$. pneumoniae infections were detected in $38(27.5 \%)$ of 138 remissions. These rates were not significantly different and suggest that patients with chronic bronchitis can undergo infections with these agents apparently without an acute worsening of their respiratory status. When rises in titers of antibody to multiple agents which occurred simultaneously during a single episode were excluded from this analysis, the distribution of single-agent infections could be assessed (table 3). Infections defined as a rise in titer of antibody to a single agent (a virus or $M$. pneumoniae) were detected in $41(24.7 \%)$ of 166 exacerbations of chronic bronchitis and only $19(13.8 \%)$ of 138 remissions, a difference which was significant $(P=0.02)$.

The frequency of individual viral and $M$. pneumoniae infections was analyzed using only these single-agent antibody titer rises (table 4). Fortyone $(82 \%)$ of 50 rises in antibody titer during

Table 2. Viral and Mycoplasma pneumoniae infections detected by serologic response alone in 46 patients with chronic bronchitis under surveillance from 1964 through 1968.

\begin{tabular}{lc}
\hline Cinical appraisal & $\begin{array}{c}\text { No. with } \\
\text { serologic evidence of } \\
\text { nonbacterial infection } \\
(\%)^{*}\end{array}$ \\
\hline Exacerbation (166) & $50(30.1)^{\dagger}$ \\
Remission (138) & $38(27.5)$ \\
\hline
\end{tabular}

${ }^{*}$ Fourfold or greater rises in CF antibody titer to influenza $A$ and $B$ viruses, parainfluenza virus types 1,2 , and 3 , respiratory syncytial virus, adenoviruses, coronaviruses, or $M$. pneumoniae. Single or multiple rises during a single episode were counted as one infection.

$\dagger$ No significant difference in infection rate between exacerbations and remissions $\left(x^{2}=0.24\right.$; one degree of freedom; $P$ not significant). 
Table 3. Viral and Mycoplasma pneumoniae infections occurring as single-agent antibody titer rises among patients with chronic bronchitis under surveillance from 1964 through 1968.

\begin{tabular}{lc}
$\begin{array}{l}\text { Clinical appraisal } \\
\text { (no. tested) }\end{array}$ & $\begin{array}{c}\text { No. with } \\
\text { serologic evidence of } \\
\text { nonbacterial infections } \\
(\%)^{*}\end{array}$ \\
\hline Exacerbation (166) & $41(24.7)^{\dagger}$ \\
Remission (138) & $19(13.8)$ \\
\hline
\end{tabular}

${ }^{*}$ Fourfold or greater rises in $\mathrm{CF}$ antibody titer to influenza $A$ and $B$ viruses, parainfluenza virus types 1,2 , and 3 , respiratory syncytial virus, adenoviruses, coronaviruses, or $M$. pneumoniae.

The difference in infection rate between exacerbations and remissions was significant $\left(\chi^{2}=5.7\right.$; one degree of freedom; $P=0.02$ ).

exacerbation were single-agent antibody titer rises, and during remission $19(50 \%)$ of the 38 rises were single-agent antibody titer rises. The higher incidence of multiple-agent antibody titer rises in remission intervals may be a reflection of the study design. More attention was paid to specimen collection during exacerbations with the result that the average intervals defined by available serum pairs were 1.5 months for exacerbation and 3.2 months for remission.

Myxovirus and coronavirus infections predominated (table 4). Influenza A virus, parainfluenza virus type 3 , and coronavirus OC43 accounted for nearly two-thirds of all infections. In each instance these infections occurred more often in exacerbation than in remission, a finding that suggests their association with the occurrence of exacerbations of chronic bronchitis; however, the difference was significant only for influenza $A$ virus and coronavirus OC43 $(P<0.05)$. All other viral infections occurred as often in exacerbation as in remission.

$M$. pneumoniae infection alone occurred in $2.4 \%$ of exacerbations but not in any remission. Fifteen additional rises in titer of antibody to $M$. pneumoniae occurred simultaneously with respiratory virus infections. These rises were equally distributed between periods of exacerbation and remission.

Viral infections among patients with chronic bronchitis occurred as defined outbreaks (figure 1). Epidemics due to influenza $A$ virus occurred during three winters, in the years 1965,1967 , and
Table 4. Occurrence of viral and Mycoplasma pneumoniae infections determined only by single-agent rises in antibody titer among patients with chronic bronchitis.

\begin{tabular}{|c|c|c|c|c|}
\hline Agent & $\begin{array}{c}\text { Exacer- } \\
\text { bations } \\
(n=166)^{*}\end{array}$ & $\begin{array}{l}\text { Remissions } \\
(n=138)^{*}\end{array}$ & $\stackrel{z}{\text { ratiot }}$ & $P$ \\
\hline \multicolumn{5}{|l|}{ Influenza virus } \\
\hline A & $15(9.0)$ & $5(3.6)$ & 1.88 & 0.030 \\
\hline B & $2(1.2)$ & $4(2.8)$ & 1.00 & NS + \\
\hline \multicolumn{5}{|c|}{ Parainfluenza virus } \\
\hline Type 1 & 0 & $1(0.7)$ & 1.06 & NS \\
\hline Type 2 & $2(1.2)$ & $2(1.4)$ & 0.15 & NS \\
\hline Type 3 & $8(4.8)$ & $4(2.9)$ & 0.85 & NS \\
\hline Adenovirus & $2(1.2)$ & $1(0.7)$ & 0.44 & NS \\
\hline $\begin{array}{l}\text { Respiratory syn } \\
\text { virus }\end{array}$ & 0 & $1(0.7)$ & 1.06 & NS \\
\hline \multicolumn{5}{|l|}{ Coronavirus } \\
\hline OCA3 & $8(4.8)$ & $1(0.7)$ & 2.10 & 0.018 \\
\hline $229 \mathrm{E}$ & 0 & 0 & 0 & NS \\
\hline M. pneumoniae & $4(2.4)$ & 0 & 1.84 & 0.033 \\
\hline
\end{tabular}

* Number of episodes in which patients had fourfold or greater CF antibody rises as evidence of infection (percentage).

†Test of significance of proportions [7].

$\$ \mathrm{NS}=$ not significant.

1968. Parainfluenza virus type 3 infection occurred also in the fall and winter months of 1964-1965 and 1967-1968 and in the fall of 1966. Coronavirus OC43 was detected predominately as one sharp cluster in the winter of 1965 ; $M$. pneumoniae was identified also during this time.

Recovery of viruses. Frozen sputum specimens were available from 113 episodes of exacerbations and from 183 remissions. More intervals were tested for recovery of virus than for $\mathrm{CF}$ antibody because of differences in the availability of frozen sputum and serum pairs. Rhinoviruses were recovered more often from the sputum of patients with chronic bronchitis during exacerbation (three [2.7\%] of 113 exacerbations) than during remission (one $[0.55 \%]$ of 183 remissions); this difference was not statistically significant. Rhinovirus infections occurred in the spring, summer, and fall. No other viruses were isolated.

Recovery of mycoplasmas. During the three years from 1966 through 1968, 36 of the 46 patients with chronic bronchitis were tested for infection by attempts at isolation of mycoplasmas from fresh sputum. All isolates were identified. M. salivarium was isolated from $215(36.3 \%)$ 
Figure 1. Temporal occurrence of fourfold or greater rises in titer of antibody to a single agent (i.e., influenza $A$ virus, parainfluenza virus type 3, coronavirus OC43, or $\mathrm{Myco}$ plasma pneumoniae) in patients with chronic bronchitis. WSSF = winter, spring, summer, fall.

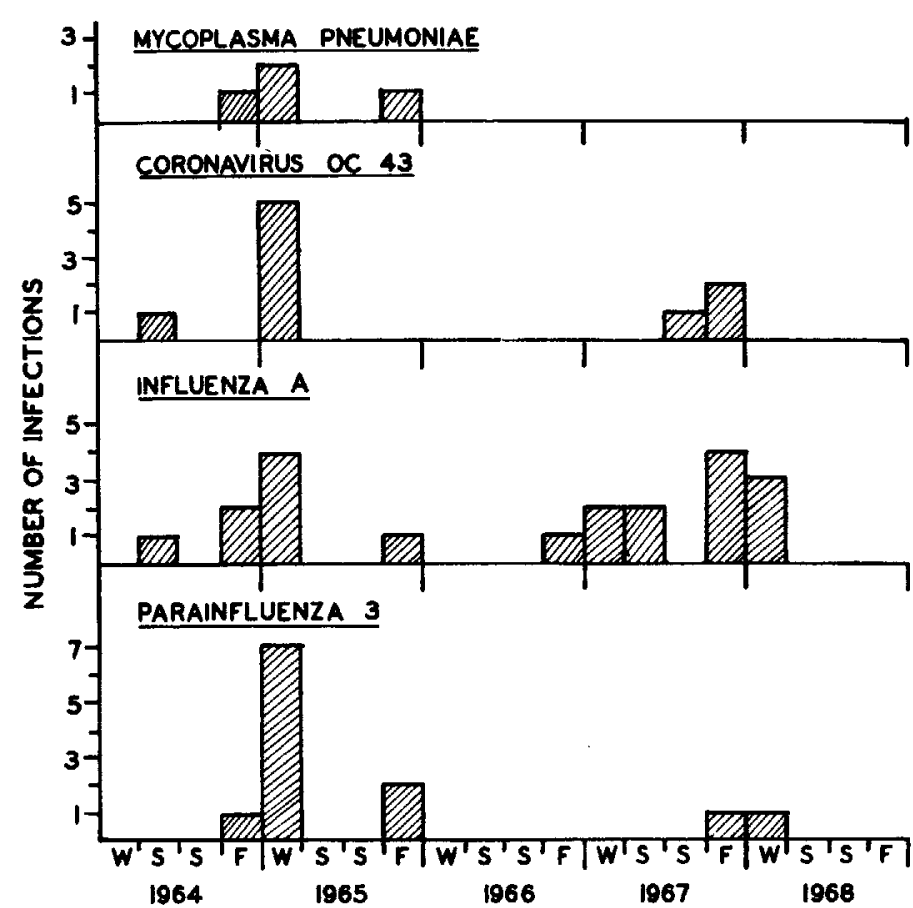

of 593 cultures. The recovery of $M$. salivarium was not related to the exacerbation or remission status of the patient. No isolates of $M$. pneumoniae or $M$. orale were recovered.

\section{Discussion}

In this study, viral and $M$. pneumoniae infections were common in patients during exacerbation, but such infections occurred also in these patients without worsening of their respiratory status. We reported our findings in two ways: as rises in titer of antibody to a single agent and as rises in titer of antibody to two or more agents within the same interval. Rises in titers of antibody to multiple agents predominated in remission intervals, which tended to be longer than exacerbation intervals. This difference may have accounted for some variation in the antibody titer which was not indicative of specific viral infection. Antibody titer rises to multiple agents also may reflect heterotypic responses and overestimate the number of infections. By analyzing antibody titer rises to single agents in this report, we estimated the importance of infection witl each specific virus, but the approach precluded assessment of the role of dual infection with two viruses or a virus and $M$. pneumoniae in exacerbations. Rises in titer of antibody to $M$. pneumoniae, however, were detected most often in association with a titer rise to one or more respiratory viruses. The possibility that $M$. pneumoniae can function as a secondary or synergistic pathogen in respiratory tract infections cannot be excluded and requires further investigation.

That viruses may play a role in exacerbations of chronic bronchitis is suggested by the finding that one-fourth of exacerbations were associated with viral infections. This rate was twice that of viral infection in remission. Infections with influenza A virus and coronavirus OC43 occurred significantly more often in exacerbations than in remissions.

Coronaviruses have been recognized recently as etiologic agents of respiratory illness in children and adults [8-10]. Gump and coworkers also reported association of these agents with exacerbations of chronic bronchitis [11]. They found that four of seven infections with coronavirus OC43 and two of seven infections with coronavirus $229 \mathrm{E}$ were associated with an exacerbation. Evidence of this relationship has accumulated very slowly because of the requirement for recovery of strain OC43 in human fetal trachea organ cul- 
tures, a difficult procedure. Infection with coronavirus $229 \mathrm{E}$ was not detected either by isolation or rise in antibody titer in the patients in our study.

The finding in this study of rhinovirus infections in only $2.7 \%$ of exacerbations is considerably lower than the $23 \%$ recovery rate for rhinoviruses in exacerbations reported by Eaclie et al. [12], the $43 \%$ by McNamara et al. [13], and the $14 \%$ and $12 \%$ by Stenhouse $[14,15]$. Carilli et al., however, failed to isolate these agents [16]. In his controlled study, Stenhouse found that rhinovirus infection was not more common in' subjects with bronchitis than in the control population, but that rhinovirus infection was more likely to be associated with the development of acute lower respiratory tract symptoms [14]. The extended period of frozen storage of specimens before tissue culture inoculation may have contrib. uted to our low recovery rate of rlinoviruses.

Sommerville first detected RSV infection in $50 \%$ of 82 exacerbations [17]. Carilli et al. [16] and McNamara et al. [13] also found RSV associated with a significant number of exacerba. tions, $17 \%$ and $12 \%$, respectively. Unlike these investigators, we detected RSV infection by serologic procedures in only one remission interval of only one of our patients.

The paucity of $M$, pneumoniae infections detected in exacerbations in this study agrees with the results of another recent report [18]. In a number of prospective studies, $M$. pneumoniae infections have been associated with $8.7 \%$ and $9.5 \%$ of exacerbations $[12,13]$ and with no exacerbations [19]. One consistent finding, however, has been the failure to recover the organism from sputum, even from patients with rising antibody titers. These results question the significance of serologic responses alone only in this infection and should be further investigated. $M$. salivarium seems ubiquitous in samples of expectorated sputum as well as in specimens obtained during bronchoscopy [20].

Our findings are similar to those reported in a number of other studies on viral and $M$. pneumoniae infections in exacerbations of chronic bronchitis (table 5). In various studies the rates of infection in exacerbations ranged widely $\left(4 \%^{-}\right.$ $64 \%$ ). These data have been interpreted as constituting strong, but not conclusive, evidence for
Table 5. Association of viral and Mycoplasma pneumoniae infections with exacerbations of chronic bronchitis.

\begin{tabular}{lrrr} 
Reference & $\begin{array}{r}\text { No. of } \\
\text { exacer- } \\
\text { bations } \\
\text { tested }\end{array}$ & $\begin{array}{c}\text { tents } \\
\text { tested } \\
\text { by serologic } \\
\text { procedures }\end{array}$ & $\begin{array}{c}\text { Percentage } \\
\text { of } \\
\text { exacer- } \\
\text { bations } \\
\text { with } \\
\text { infection }\end{array}$ \\
\hline Sommerville [17] & 82 & 1 & 50 \\
Carilli et al. [16] & 46 & 8 & 52 \\
Eadie et al. [1 2] & 75 & 6 & 21 \\
Stark et al. [21] & 185 & 3 & 7 \\
Ross et al. [19] & 125 & 9 & 16 \\
Stenhouse [14] & 56 & 1 & 14 \\
Moffat and Suth- & & & \\
$\quad$ erland [22] & 68 & 12 & 4 \\
Stenhouse [15] & 64 & 11 & 12 \\
McNamara et al. [13] & 42 & 5 & 64 \\
Fisher et al. [23] & 63 & 7 & 14 \\
Gump et al. [11] & 116 & 11 & 34 \\
Lamy et al. [24] & 49 & 10 & 63 \\
Present study & 166 & 11 & 25 \\
\hline
\end{tabular}

*Includes rhinovirus recovery when appropriatc tissue cultures were used for isolation of these agents.

an etiologic role of viruses or $M$. pneumoniae in the pathogenesis of acute exacerbations of chronic bronchitis. However, the available data cannot be easily compared because different sam. pling procedures and methods were employed. In addition, individual authors often did not specify the number of remission intervals examined but reported only infections detected during exacerbations and compared patients with chronic bronchitis with healthy (control) populations. Furthermore, the definition of an exacerbation is a subjective judgment, and different interpretations of the criteria will affect the percentage of association with infection.

Two groups of investigators have derived a more striking correlation of infection with exacerbation by interpreting their findings in a timeweighted fashion. Thus Gump et al. found that the incidence of infection was $32 \%$ per patient week of exacerbation but only $0.9 \%$ per patient week spent in remission [11]. Similarly, Lamy et al. compared patient months spent in exacerbation and remission with an incidence of infection of $52 \%$ and $3.7 \%$, respectively [24]. Our data did not permit a time-weighted analysis since the duration of exacerbation was not recorded. When 
the duration of exacerbation was estimated using the interval between the collection of two samples of serum bracketing an exacerbation, we tested 257 months of exacerbation and 442 months of remission. The rate of viral infection was $15.4 \%$ per exacerbation month and $4.3 \%$ per remission month. This trend is similar to that in the data of Gump et al. [11].

A special problem in interpretation is posed by the detection of infection in patients with chronic bronchitis without an associated acute compromise in their respiratory status. In our study approximately one-third of all viral and $M$. pneumoniae infections detected belonged in this category. Whether subclinical infections contribute to continuing clinical deterioration remains unexplored, and long-term epidemiologic and clinical surveillance of patients with chronic bronchitis will be required to answer this question.

\section{References}

1. Leeder, S. R. Role of infection in the cause and course of chronic bronchitis and emphysema. J. Infect. Dis. 131:731-742, 1975.

2. Tager, I., Speizer, F. E. Role of infection in chronic bronchitis. N. Engl. J. Med. 292:569-571, 1975.

3. Mufson, M. A., Saxtan, D., Shultz, P. S., Buscho, R. O., Finch, E. Virus and mycoplasma infections in exacerbations of chronic bronchitis. Clin. Res. 22:646A, 1974.

4. Definition and classification of chronic bronchitis for clinical and epidemiological purposes. A report to the Medical Research Council. Lancet 2:775-779, 1965.

5. Mufson, M. A., Chang, V., Gill, V., Wood, S. C., Romansky, M. J., Chanock, R. M. The role of viruses, mycoplasmas and bacteria in acute pneumonia in civilian adults. Am. J. Epidemiol. 86:526-544, 1967.

6. Clyde, W. A., Jr. Mycoplasma species identification based upon growth inhibition by specific antisera. J. Immunol. 92:958-965, 1964.

7. Croxton, F. E. Elementary statistics with applications in medicinc. Prenticc-Hall, New York, 1953, p. 263265.

8. Wenzel, R. P., Hendley, J. O., Davies, J. A., Gwaltney, J. M., Jr. Coronavirus infections in military recruits: three-year study with coronovirus strains OC43 and 229E. Am. Rev. Respir. Dis. 109:621-624, 1974.

9. Monto, A. S., Lim, S. K. The Tecumseh study of respi- ratory illness. VI. Frequency of and relationship bew'een outbreaks of coronavirus infection. J. Infect. Dis. 129:271-276, 1974.

10. McIntosh, K., Chao, R. K., Krause, H. E., Wasil, R., Mocega, H. E., Mufson, M. A. Coronavirus infection in acute lower respiratory tract disease of infants. $\mathrm{J}$. Infect. Dis. 130:502-507, 1974 .

11. Gump, D. W., Phillips, C. A., Forsythe, B. R., McIntosh, K., Lamborn, K. R., Stouch, W. H. Role of infection in chronic bronchitis. Am. Rev. Respir. Dis. 113: $465-474,1976$.

12. Eadie, M. B., Scott, E. J., Grist, N. R. Virological studics in chronic bronchitis. Br. Mcd. J. 2:671-673, 1966.

13. McNamara, M. J., Phillips, I. A., Williams, O. B. Viral and Mycoplasma pneumoniae infections in exacerbations of chronic lung disease. Am. Rev. Respir. Dis. 100:19-24, 1969 .

14. Stenhouse, A. C. Rhinovirus infection in acute exacerbation of chronic bronchitis: a controlled prospective study. Br. Med. J. 3:461-463, 1967.

15. Stenhouse, A. C. Viral antibody levels and clinical status in acute exacerbations of chronic bronchitis: a controlled prospective study. Br. Med. J. 3:287-290. 1968.

16. Carilli, A. D., Gohd, R. S., Gordon, W. A virologic study of chronic bronchitis. N. Engl. J. Med. 270: 123-127, 1964.

17. Sommerville, R. G. Respiratory syncytial virus in acute exacerbations of chronic bronchitis. Lancet 2:1247$1248,1963$.

18. Westerberg, S. C., Smith, C. B., Renzetti, A. D. Mycoplasma infections in patienits with chronic obstructive pulmonary disease. J. Infect. Dis. 127:491-497, 1973.

19. Ross, C. A. C., McMichael, S., Eadie, M. B., Lees, A. W., Murray, E. A., Pinkerton, I. Infective agents and chronic bronchitis. Thorax 21:461-464, 1966.

20. Cherry, J. D., Taylor-Robinson, D., Willers, H., Stenhouse, A. C. A search for mycoplastna infections in patients with chronic bronchitis. Thorax 26:62-67, 1971.

21. Stark, J. E., Heath, R. B., Curwen, M. P. Infection with influenza and parainfluenza viruses in chronic bronchitis. Thorax 20:124-127, 1965.

22. Moffat, M. A. J., Sutherland, J. A. W. Persistence of viral antibodies in patients with chronic bronchitis. Br. Med. J. 1:601-603, 1967.

23. Fisher, M., Akhtar, A. J., Calder, M. A., Moffat, M. A. J., Stewart, S. M., Zealley, H., Crofton, J. W. Pilot study of factors associated with exacerbations in chronic bronchitis. Br. Med, J. 4:187-192, 1969.

24. Lamy, M. F., Pouthicr-Simon, F., Debacker-Willame, E. Respiratory viral infections in hospital patients with chronic bronchitis: observations during periods of exacerbation and quiescence. Chest $63: 336-341$, 1973. 